\title{
Ethnologies
}

\section{Retro Ball Parks: Instant History, Baseball, and the New \\ American City. By Daniel Rosensweig. (Knoxville: The University of Tennessee Press, 2005. Pp. 214, ISBN 1-57233-351-0)}

\section{Neil White}

Volume 30, numéro 1, 2008

Danse au Canada

Dance in Canada

URI : https://id.erudit.org/iderudit/018842ar

DOI : https://doi.org/10.7202/018842ar

Aller au sommaire du numéro

\section{Éditeur(s)}

Association Canadienne d'Ethnologie et de Folklore

ISSN

1481-5974 (imprimé)

1708-0401 (numérique)

Découvrir la revue

Citer ce compte rendu

White, N. (2008). Compte rendu de [Retro Ball Parks: Instant History, Baseball, and the New American City. By Daniel Rosensweig. (Knoxville: The University of Tennessee Press, 2005. Pp. 214, ISBN 1-57233-351-0)]. Ethnologies, 30(1),

180-183. https://doi.org/10.7202/018842ar d'utilisation que vous pouvez consulter en ligne.

https://apropos.erudit.org/fr/usagers/politique-dutilisation/ 
she sees in the humble, ephemeral memorials that sprout like mushrooms after a summer rain along the roadsides of regions throughout this and other countries.

Karen Baldwin

East Carolina University

Greenville, North Carolina

\section{Reference \\ Foote, Kenneth. 2003. America's Landscapes of Violence and Tragedy. Austin: University of Texas Press.}

Retro Ball Parks: Instant History, Baseball, and the New American Clty. By Daniel Rosensweig. (Knoxville: The University of Tennessee Press, 2005. Pp. 214, ISBN 1-57233-351-0)

Daniel Rosensweig's Retro Ball Parks analyzes the impact of Jacob's Field - a "new old" baseball park that combines elements of rare "classic" parks like Boston's Fenway and Chicago's Wrigley Field — in downtown Cleveland's revitalized Gateway tourist district, as well as the park's meaning in twenty-first century American culture. Since 1990, an unequal alliance between Cleveland's municipal government and the mercenary Indians franchise led local officials to pay for the construction of the new diamond, a professional basketball arena, related infrastructure, and employees' wages to the tune of over $\$ 1$ billion. Astronomical public subsidies helped "augment the profit of two sports clubs that... might be profitable without" them (13). Similar municipalcorporate alliances have occurred across the United States in the last two decades. The reconstitution of downtowns from commerce to tourism (xi) continues unabated, and, according to Rosensweig, Cleveland leads the pack in scale and depth of public subsidy and planning.

Yet Retro Ball Parks is mainly a study of popular culture and sociocultural theory, not economics or sports and leisure history. It focuses on the cultural, not the financial or political, significance of new old fields (11). To Rosensweig, retro parks offer wealthy residents and tourists vicarious, non-threatening encounters with the carnivalesque marginality of urban life through carefully commodified team histories, 
the exclusion of contemporary black and poor faces, and the parks' location in former slums long avoided by the middle class. According to Rosensweig, the consumer's experience at Jacob's Field exemplifies atomized middle-class Americans' longing to be a part of an authentic community and to establish psychic links to a past Golden Age. Rosensweig illustrates - often in original ways - how urban boosters succeed in reshaping downtown space but fail to solve the black/white, rich/poor, urban/suburban binaries of American society in local places. Cleveland's Gateway actually reinforces those contradictions.

The first three chapters set the big picture. Chapter one provides the recent history and a physical description of the parks while two and three chart the rise of baseball's popularity in American society since the mid-nineteenth century. Rosensweig's considerable knowledge of baseball history establishes the significance of the contemporary retro fad. He describes the ongoing struggle between moral reformers who saw baseball as a way to instill workers with middle-class values, and those, like St. Louis Browns' owner Chris von der Ahe (78-79), who believed baseball was a carnival where the lower classes could indulge their baser instincts. In the late 1940s desegregation briefly reconciled the two strains; baseball became an established spectacle that all Americans could enjoy. Yet that momentary consensus collapsed because of white flight to the suburbs. Later multipurpose stadiums ashtray shaped and set apart from their surroundings in seas of parking spaces - confirmed the gulf between city and suburb, spectator and owner, black and white. In the juxtaposition of elements from classic venues, argues Rosensweig, retro parks promise a new reconciliation while, more importantly, easing fans' consumption of corporate product.

The next three chapters elaborate upon the deeper cultural meaning of retro parks. Chapter four analyzes the experience of what Rosensweig identifies as true fans - bleacher bums or bleacher creatures - and the recent marketing of the cheap seats as the "hip" place to sit. Five explains how white America's fear of black males' presumed physical superiority has been sanitized and commodified at new old parks. Blacks are only visible in historical exhibits or on-field — in the acceptable capacity of performers - while poor resident blacks are excluded from tourist districts. Chapter six theorizes the broader cultural meaning of the previous chapters through an extended comparison to Don DeLillo's seminal postmodern novel Underworld. Ultimately, Rosensweig paints a disturbing picture of an America where simulation trumps authenticity. 
He concedes that consumers shape the "texture of the area's history" through a "multiplicity of consuming strategies" (174), but his overarching contention remains one of pessimistic resignation in the face of simulacra triumphant.

Conceptually, Rosensweig begins with a plausible, qualified thesis - that the creation and packaging of Jacob's Field mimics the binaries of city life in American society - but, by chapter six, he sounds the death knell of authentic experience and history in America (147, 151, 166-167). He arrives at this metathesis not through systematic analysis of a sizeable body of empirical evidence, but by observations made strolling the streets of Cleveland's Gateway (xi and 19), privileging the works of cultural theorist Jean Baudrillard over sports and leisure specialists, and linking tenuously real historical events to works of fiction like Underworld and the Tom Berenger B-movie, Major League. Broader comparison and far more direct evidence are required for the larger claim to be credible.

Rosensweig projects his frustrated adolescent fantasies of "slumming it" with the noble savages of inner-city Baltimore onto the majority of the baseball-watching public. Like his personal bemoaned experience of "cheap grace" at the ball park $(1-8,14,20)$, Rosensweig's middleclass protagonists never achieve the authenticity they seek. They remain, presumably, locked in an endless cycle of chronic postmodern angst relieved momentarily by the fleeting catharsis of monetary binges. Apart from the failure to quantify this "condition" and make it plausible, there is a problem of scale. The result of these mass individual psychodramas is, no doubt, far less troubling to corporate shareholders. Urban and material historian John D. Fairfield - a frequent critic of corporate sport not cited by Rosensweig - describes the retro park fad as a form of corporate welfare that does not revitalize urban municipalities in any sustainable way. The small benefits of retro parks pale in comparison to the handouts given to unaccountable corporations better spent on infrastructure, education, and other social services. Compared to the erosion of public space and corporate irresponsibility signified by retro developments, ticketholders' existential traumas run a distant third.

Core concepts like "reality" and "authenticity" are undefined and central questions are unanswered. Rosensweig never explains why workers' and African Americans' lives are somehow more real than those of middle-class suburbanites. Do suburbs and the people who inhabit them somehow not exist in physical space? Are urban spaces 
better than suburbs on an objective scale of human habitation? The silences beg the basic question, "Can an escapist stick and ball game accurately gauge authenticity?"

Retro Ball Parks is an interesting but ultimately unsatisfying study. Considering contemporary baseball's immersion in a neo-liberal economy where corporate mobility and profit margins preclude social spending, the topic deserves a fuller economic and historical treatment. A relatively brief, single case study cannot be convincing on the controversial points Rosensweig pursues, unless the reader is convinced before opening the book.

Neil White

McMaster University

Hamilton, Ontario

\section{Reference}

Fairfield, John D. 2001. "The Park in the City": Baseball Landscape Civically Considered. Material History Review 54: 21-39.

Goddesses and Monsters: Women, Myth, Power, and Popular Culture. By Jane Caputi. (Madison: University of Wisconsin Press, 2004. Pp 468, ISBN 0-299-19624-0)

There are certain works that are considered classics when it comes to interpreting mythology in the context of culture; Sir James G. Frazer's The Golden Bough, for example, or Joseph Campbell's The Hero with a Thousand Faces. It has long been recognized, however, that these classics tended to reflect a very Western, white, straight male-centric point of view, to the exclusion of all others. Also, these works focused on things of the past rather than more modern culture. They lose a large degree of their relevance now that the majority of Westerners no longer receive a classical (or even Biblical) education.

Since the end of the Second World War, however, there has been a concerted effort to draw links between our contemporary culture and those of the past. Some scholars have taken advantage of the interest in such modern mythologies as Tolkien's Middle-Earth or Lucas' "galaxy far, far away" to reintroduce the ancient stories, albeit with a different interpretation. Other scholars, such as Marshall McLuhan, have also taken on the formidable task of interpreting today's culture in a mythological way. Goddesses and Monsters is one such work. 